\title{
Darbo aplinkos veiksnių poveikio sveikatai ekspertizè pulmonologijoje
}

Rita Raškevičiené

LSMU MA Pulmonologijos ir imunologijos klinika

Reikšminiai žodžiai: lètinès plaučių ligos, su darbu susijusios ligos, profesinės ligos, darbo medicina.

Santrauka. Galimo etiologinio ar ligą skatinančio veiksnio (darbo, namų aplinkoje esančio rizikos veiksnio) išsiaiškinimas ir pašalinimas laiku sudaro sąlygas efektyvesniam gydymui ir gali užkirsti kelią tolesniam ligos progresavimui, lemiančiam ilgalaiki nedarbingumą, 0 ilgainiui ir neigalumą. Yra tokių alerginių bei kvejpavimo takų ligų, kuriomis sergantis asmuo negali dirbti veikiamas cheminių veiksnių, pvz.: lètinès obstrukcinès plaučių ligos, astma, lètinis kvèpavimo nepakankamumas, viršutinių kvèpavimo takų atrofiniai pakitimai. Gydytojas, nustatęs alerginę ar lètinę plaučių ligą ir j̨taręs, kad ligos eigą gali bloginti paciento darbo sąlygos, turètų siųsti ji darbo medicinos gydytojo konsultacijos.

Šiandieninèje darbo aplinkoje darbuotojus dažnai vienu metu veikia keletas žalingų veiksnių, kurių kompleksinis poveikis turi itakos tiek profesinei, tiek ir neprofesinei ligai atsirasti. Galimo etiologinio ar ligą skatinančio veiksnio (darbo, namų aplinkoje esančio rizikos veiksnio) išsiaiškinimas ir pašalinimas laiku sudaro sąlygas efektyvesniam gydymui ir gali užkirsti kelią tolesniam ligos progresavimui, lemiančiam ilgalaiki nedarbingumą, o ilgainiui ir neigalumą. Ne veltui dar 17 amžiuje Bernardino Ramazzini, laikomas darbo medicinos tèvu, visiems gydytojams nurodè klausti apie paciento profesiją, užsiemmimo pobūdį. Darbas aplinkoje, užterštoje dulkėmis ar cheminių junginių garais, gali provokuoti ar sunkinti kvèpavimo takų ir/ ar alerginès ligos eigą.

Siekiant išsaugoti darbuotojų sveikatą ir darbingumą, užkirsti kelią sveikatos sutrikimams atsirasti bei nustatyti ligas ankstyvos stadijos, atliekami privalomi darbuotu sveikatos tikrinimai. Jie gali būti išankstiniai (prieš pradedant dirbti), periodiniai (dirbant) ir neeiliniai (nesilaikant periodiškumo). Už darbuotojo siuntimą tikrintis sveikatos profilaktiškai atsako darbdavys. Jis išduoda Asmens medicininę knygelę F 048/a, kurioje privalo nurodyti darbuo- toją veikiančius kenksmingus ir/ar pavojingus veiksnius. Privalomus profilaktinius darbuotojų sveikatos tikrinimus atlieka darbo medicinos gydytojas arba šeimos gydytojas, išklausęs 36 val. darbo medicinos kursą, privalomai arba prireikus konsultuodamasis su kitais gydytojais specialistais: alergologais, pulmonologais, otorinolaringologais, radiologais ir kt. Kiekvienas sveikatą tikrinantis gydytojas atsako už sveikatos tikrinimo kokybę ir įrašo tikrinimo rezultatus į F Nr.25/a. Galutini sprendimą dèl darbuotojo profesinio tinkamumo (galimybės dirbti darbą) priima darbo medicinos gydytojas arba šeimos gydytojas, ịvertinęs gydytojų specialistu konsultacijas ir tyrimų rezultatus. Taigi gydytojai specialistai taip pat turètų žinoti rizikos veiksnių poveikị sveikatai.

\section{PROFESINIO TINKAMUMO EKSPERTIZĖ}

LR Sveikatos apsaugos ministro 2000 m. gegužès mėn. 31 d. ísakymo Nr. 30113 priede, reglamentuojančiame asmenų, dirbančiu darbo aplinkoje, kurioje galima profesinè rizika (kenksmingu veiksnių poveikis ir/ar pavojingas darbas), privalomo sveikatos tikrinimo tvarką, nurodoma, 
Lentelè. Profesinès rizikos veiksniai, kuriems esant negalima dirbti kvèpavimo takų bei alerginèmis ligomis sergantiems ligoniams

\begin{tabular}{l} 
Liga/TLK kodas \\
\hline Plaučių tuberkuliozė (A15) \\
Viršutinių kvėpavimo takų atrofiniai pakitimai \\
(J30-J31, J37-J39) \\
Lètinès obstrukcinès plaučiụ ligos (J44-47) \\
Lètinis kvėpavimo nepakankamumas (J96.1)
\end{tabular}

Viršutinių kvèpavimo takų atrofiniai pakitimai (J30-J31, J37-J39)

Lètinès obstrukcinès plaučių ligos (J44-47)

Lètinis kvėpavimo nepakankamumas (J96.1)

\section{Draudžiamos darbo sąlygos}

Dulkès (anglies, abrazyvų, augalinès ir gyvulinės kilmès, metalų ir jų lydinių, neorganiniụ liuminoforų, silicio dioksido)

\begin{abstract}
Akrilonitrilo, alifatinių aminų (etanolaminas, metilaminas), asbesto, arseno ir jo junginių, azoto rūgšties, azoto oksidų, amoniako, ftalio rūgšties, ftalatų, bromo ir jo junginių, chloro ir jo junginių, chromo ir jo junginių, fosforo ir jo junginių, fluoro ir jo junginių, kadmio ir jo junginių, koksavimo dujų, sieros ir jos junginių (sieros rūgštis, sieros oksidai, sieros vandenilis), sintetinių skalbimo priemonių, stibio ir jo junginių, urzolio ir urzolinių dažu, vandenilio peroksido poveikis

Plastikų gamyba epichlorhidrino, fluoro, silicio organinių junginių pagrindu Suvirintojo darbas

Alifatiniu angliavandeniliu halogenintu dariniu (dichloretanas, anglies tetrachloridas), anglies disulfido, aromatinių aminụ (benzidinas, naftilaminai), aromatinių angliavandenilių halogeninių darinių, bario junginių, ciano vandenilio rūgšties ir jos junginių, fenolių ir juc darinių, formaldehido, hidrazino ir jo junginių, metilacetato, naftos, jos perdirbimo produktų, benzino, ozono, seleno poveikis

Darbas su retaisiais žemès elementais ir tauriaisiais metalais (auksas, sidabras), jų junginiais ir lydiniais

Plastikų gamyba stireno, vinilchlorido, chloretileno pagrindu
\end{abstract}

Lètinès obstrukcinès plaučių ligos (J44-47) Lètinis kvėpavimo nepakankamumas (J96.1)
Viršutinių kvėpavimo takų atrofiniai pakitimai Dirbtinio sintetinio pluošto, izocianatų, pentano, pesticidų, skalūnų dervos poveikis (J30-J31, J37-J39)

Astma (J45)

\begin{tabular}{|c|c|}
\hline Astma (J45) & Stireno, sintetinio kaučiuko poveikis \\
\hline $\begin{array}{l}\text { Viršutinių kvėpavimo takų atrofiniai pakitimai } \\
\text { (J30-J31, J37-J39) } \\
\text { Lėtinės obstrukcinės plaučių ligos (J44-47) } \\
\text { Lėtinis kvėpavimo nepakankamumas I-II }{ }^{\circ} \text { (J96.1) }\end{array}$ & $\begin{array}{l}\text { Alergenų, skirtuc diagnostikai ir gydymui, poveikis, darbas su kraujo ir imunobiologiniais } \\
\text { preparatais, antibiotikais }\end{array}$ \\
\hline $\begin{array}{l}\text { Alerginès odos ligos (L23) } \\
\text { Lètinès obstrukcinės plaučiu ligos (J44-J47) } \\
\text { Lėtinis kvėpavimo nepakankamumas (J96.1) }\end{array}$ & $\begin{array}{l}\text { Farmakologinės priemonès (vitaminai, hormonai, antibiotikai, citostatikai) jų gamyba ir } \\
\text { naudojimas, mangano ir jo junginių, nikelio ir jo junginių poveikis }\end{array}$ \\
\hline $\begin{array}{l}\text { Alerginès odos ligos (L23-L24) } \\
\text { Viršutinių kvèpavimo takų atrofiniai pakitimai } \\
\text { (J30-J31, J37-J39) } \\
\text { Lėtinės obstrukcinès plaučių ligos (J44-J47) } \\
\text { Lètinis kvėpavimo nepakankamumas (J96.1) }\end{array}$ & $\begin{array}{l}\text { Metalų (kobaltas, vanadis, molibdenas, titanas, cirkonis, volframas, kadmis) ir jų junginių } \\
\text { poveikis } \\
\text { Plastikai ir sintetinès dervos akrilinès ir metakrilinès rūgšties, etileno, propileno, poliami- } \\
\text { dụ pagrindu gamyba, } \\
\text { Epoksidinių dervų ir plastikų gamyba fenolio, formaldehido pagrindu }\end{array}$ \\
\hline
\end{tabular}

jog asmenims, sergantiems bet kurios lokalizacijos tuberkulioze, kurie išskiria mikobakterijas, lètinėmis kvėpavimo takų ligomis (bronchitas, emfizema, LOPL, astma, bronchektazès), kai yra indikacijų taikyti ilgalaikę oksigenoterapiją, dirbti profesinès rizikos sąlygomis draudžiama, t. y. šie asmenys negali dirbti jokio kenksmingo ar/ir pavojingo darbo. Be to, yra alerginių bei kvejpavimo taku ligų, kuriomis sergantis asmuo negali dirbti veikiamas tam tikrų rizikos veiksnių. Pavyzdžiui, lètinès obstrukcinès plaučių ligos, astma, lètinis kvèpavimo nepakankamumas, viršutinių kvejpavimo takų atrofiniai pakitimai yra kontraindikacija dirbti aplinkoje, kur veikia daugelis cheminių veiksnių (lentelè), naktinio darbo neturètų dirbti sergantys LOPL, astma, intersticinėmis plaučių ligomis (TLK kodas J80, J84), padidejjusio atmosferos slègio sąlygomis (narais) negali dirbti sergantys astma, lètinėmis obstrukcinèmis plaučių ligomis bei turintys lėtini kvèpavimo nepakankamumą asmenys.

Ne paslaptis, kad tikrinami darbuotojai, baimindamiesi prarasti darbo vietą, neatskleidžia savo sveikatos problemų, slepia ligas ir net neigalumą, tad tikrinant sveikatą profilaktiškai kontraindikacijos dirbti išsiaiškinamos nedažnai. Tokiais atvejais liga, nepaisant taikomo intensyvaus gydymo, dažnai atsinaujina ir progresuoja, ypač tai pasakytina apie astmą ir kitas alergines ligas. Nors kai kurių užsienio autorių nuomone, tinkamai sureguliavus gydymą bei kontroliuojant ligą, žmogus ir toliau gali likti savo darbo vietoje ir tęsti darbą. Vis dèlto tai įmanoma tik tuo atveju, jeigu atitinkamai kontroliuojami ir koreguojami darbo aplinkos veiksniai: jie turi būti pašalinti iš darbo vietos ar kiek įmanoma sumažintas ju poveikis taip, kad nekenktų sveikatai [2]. Tai įmanoma tik tada, kai darbų 
sauga ir profesinė sveikatos priežiūra įmonèje funkcionuoja efektyviai, ir darbo vieta yra individualiai pritaikoma sergančiam darbuotojui. Tenka apgailestauti, kad daugumoje Lietuvos įmonių, ypač smulkiose ir vidutinèse, profesinès sveikatos priežiūros iš viso nèra, todèl susirgę darbuotojai nekeisdami darbo vietos rizikuoja savo sveikata: gydymas nèra efektyvus, liga progresuoja, lemia ilgalaikị nedarbingumą, ilgainiui ir neigalumą, o tai reiškia padidejusias išlaidas tiek darbdaviui, tiek sveikatos apsaugos sistemai.

\section{DARBO MEDICINOS GYDYTOJO VAIDMUO}

Darbo medicinos gydytojo funkcija - ivertinti darbuotojo profesini tinkamumą, konsultuoti darbuotojus bei darbdavius įvairiais su profesine sveikata susijusiais klausimais, užtikrinti nepavėluotą profesinių ligų diagnostiką.

Paprastai pacientai matydami, jog darbo sąlygos blogina ligos eigą, mano, jog liga profesinè. Tačiau ši nuostata ne visuomet teisinga. Profesinè liga - ūminis ar lètinis darbuotojo sveikatos sutrikimas, kurị sukèlè vienas ar daugiau kenksmingu ir/ar pavojingu darbo aplinkos veiksnių, nustatyta tvarka pripažintas profesine liga. Tai ligos, išvardytos Lietuvos profesinių ligų sąraše, kurių tiesioginė ir pagrindinè priežastis yra profesinio veiksnio poveikis. Profesinè liga nustatoma tik tiems asmenims, kurie yra drausti socialiniu draudimu dèl nelaimingu atsitikimuc darbe ir profesinių ligų. Profesinès ligos diagnozę gali patvirtinti tik darbo medicinos gydytojas, detaliai ištyręs ir ịvertinęs darbuotojo sveikatos sutrikimus ir jų sąsajas su darbo sąlygomis. Todèl visais atvejais iškilus neaiškumams dèl paciento darbo sąlygu neigiamo poveikio sveikatai, jo galimybès tęsti darbą ar įtariant galimą profesinę ligą būtina pacientą siųsti darbo medicinos gydytojo konsultacijos.

A. B., 45 metuc, dirbanti siuvèja dulkètoje aplinkoje, buvo atsiųsta pas darbo medicinos gydytoją konsultuotis dèl ịtariamos profesinès ligos. Dgn.: Bonchoectasiae lobi inferioris dextri. Asthma non allergicum persistens.

Pacientè skundžiasi kosuliu, dažnais dusulio priepuoliais. Simptomai vargina apie 10 metuc, prieš 12 metų nustatyta bronchektazès dešiniajame plautyje. Moteris teigia, kad darbe ar bet kokioje dulkètoje aplinkoje simptomai sustiprejja, pakyla temperatūra, atsiranda kosulys su skrepliavimu.

Šiuo atveju nèra pagrindo teigti, jog liga profesinè: nors ligos simptomai ir paūmèjimai susiję su darbo aplinkos veiksnių poveikiu, tačiau nèra tiesioginis ligą sukèlęs veiksnys, nes paūmèjimus provokuoja bet kokios dulkès, esančios tiek darbo, tiek namų aplinkoje. Taigi pacientei dirbti dulkètoje aplinkoje negalima, bet ji gali dirbti pagal savo specialybę aplinkoje, kurioje nèra dirginančių alergenų.

\section{EXPERTISE OF OCCUPATIONAL RISK FACTORS' IMPACT ON LUNG DISEASES}

\section{RITA RAŠKEVIČIENE்}

DEPARTMENT OF PULMONOLOGY AND IMUNOLOGY, HOSPITAL OF LITHUANIAN UNIVERSITY OF HEALTH SCIENCES KAUNAS CLINICS

Keywords: chronic lung diseases, work related diseases, occupational diseases, occupational medicine.

Summary. Detection and removal of possible etiological or predisposing conditions (risk factors at work or home environment) of a disease makes treatment more effective and prevents further progression of the disease that can lead to long-term absenteeism, and eventual disability. Chronic obstructive pulmonary diseases, asthma, chronic respiratory failure, atrophic changes of upper respiratory tract are contraindications for work under exposure to chemical factors. Therefore, a doctor finds an allergic or chronic lung disease, suspecting that the disease can be worsened by the patient's workplace conditions should be directed to the occupational physician consultation.

\section{LITERATŪRA}

1. R. Ustinavičienè, V. Obelenis, T. Bagdonienè ir kt. Darbo medicina.VDI, Vilnius, 2007

2. Lawrence Martin, Occupational Asthma /prieiga per: http://www.lakesidepress.com/pulmonary/OccupationalAsthma.htm 